\title{
Andrzej Niemiec
}

Uniwersytet Ekonomiczny w Poznaniu e-mail: andrzej.niemiec@ue.poznan.pl

\section{ISTOTNOŚĆ JAKO PODSTAWOWE KRYTERIUM SELEKCJI KLUCZOWYCH MIERNIKÓW DOKONAŃ (KPIS)}

\section{IMPORTANCE AS THE MAIN CRITERION OF KEY PERFORMANCE INDICATORS PRIORITIZATION}

DOI: $10.15611 / \mathrm{pn} .2017 .472 .25$

JEL Classification: L2, L25, G3

Streszczenie: Istotność kluczowych mierników dokonań jest często uważana za podstawowe kryterium ich wyboru na potrzeby zarządzania dokonaniami. Jest ono ideą szeregu metod selekcji kluczowych mierników dokonań na etapie tworzenia i ewaluacji ich systemu. Celem artykułu jest weryfikacja empiryczna tego kryterium, a zarazem wybranej metody selekcji KPIs. W trakcie badań ankietowych zidentyfikowano szereg mankamentów wybranej metody selekcji KPIs, takich jak: promowanie wskaźników syntetycznych - opóźnionych, które powinny stanowić jedynie $20 \%$ mierników, rekomendowanie pomiaru procesów i zjawisk „na wyjściu”, jak obszar finansów czy klienta, oraz znaczna subiektywność wyniku w zależności od dobranej próby badawczej. Konkluzją jest stwierdzenie, że metody selekcji KPIs oparte jedynie na kryterium istotności miernika powinny być, co najwyżej, metodami uzupełniającymi proces selekcji mierników KPIs.

Słowa kluczowe: kluczowe mierniki dokonań, KPIs, istotność, selekcja.

Summary: The importance of key performance indicators is often regarded as a basic criterion for their selection in performance management. It is the main idea of many prioritization methods of key performance indicators, at the stage of development and evaluation of their system. The aim of the article is the empirical verification of this criterion, and chosen method of KPIs prioritization.During the survey a number of disadvantages of the chosen method were identified, such as: promotion of synthetic, lag indicators, which should constitute only $20 \%$ of measures set, favouring the „output" connected to the financials, or a client, strong dependence of the selected study sample. The conclusion is that the importance criterion methods of KPIs prioritization should be used only as a complementary methods of KPIs selection.

Keywords: key performance indicators, KPIs, importance, prioritization. 


\section{Wstęp}

Ponad 20 lat temu M.J. Lebas pisał, że zarządzanie dokonaniami (performance management) jest filozofią wspomaganą przez pomiar dokonań (performance measurement) [Lebas 1995, s. 34]. Pomiar dokonań i zarządzanie dokonaniami nie mogą być rozdzielone. Wszyscy ci, którzy koncentrują się wyłącznie na pomiarze, bez zrozumienia, że mierniki odzwierciedlają konsekwencje podejmowanych decyzji, nie mieli szansy na przejęcie kontroli nad procesem tworzenia dokonań i osiągnięcie sukcesu firmy lub zarządzanej jednostki organizacyjnej [Lebas 1995, s. 35]. Pogląd ten potwierdzają późniejsze prace. B. Marr w swoich badaniach zidentyfikował narzędzia stosowane przez przedsiębiorstwa w praktyce zarządzania dokonaniami. Podstawowym z nich (w opinii ponad 77\% respondentów) są kluczowe mierniki dokonań (KPIs, Key Performance Indicators') [Marr 2012, s. 7].

Kluczowe mierniki dokonań według UK Companies Act z 2006 roku są to „czynniki, za pomocą których można skutecznie mierzyć rozwój, dokonania lub pozycję (konkurencyjną) przedsiębiorstwa" [Companies Act 2006].

Istotność kluczowych mierników dokonań jest często uważana za podstawowe kryterium ich wyboru na potrzeby zarządzania dokonaniami. Jest ono ideą szeregu metod selekcji kluczowych mierników dokonań na etapie tworzenia i ewaluacji ich systemu. Celem artykułu jest weryfikacja empiryczna tego kryterium, a zarazem wybranej metody selekcji KPIs.

\section{Kryterium istotności (importance) kluczowych mierników dokonań}

Paulen i Finken definiują KPIs jako kluczowe mierniki organizacji, które napędzają dokonania przedsiębiorstwa [Paulen, Finken 2009]. Pomimo iż są one kluczowym elementem zarządzania dokonaniami, od którego zależy jakość zarządzania - dobór ich jest często dyskusyjny. Idealnie, jeżeli jest poparty sprawdzoną metodologią. Dobrze, jeżeli zależy od czynników racjonalnych. Niestety, w praktyce firm doradczych wybór zależy często od mody, a więc czynnika nieuzasadnionego racjonalnie.

W praktyce selekcji kluczowych mierników dokonań z zastosowaniem sprawdzonej metodologii od lat funkcjonuje kryterium istotności, w ramach którego można zidentyfikować szereg metod i technik rangujących mierniki dokonań. Najwyższe miejsca $\mathrm{w}$ rankingu istotności uzyskują zgodnie $\mathrm{z}$ tym podejściem mierniki, które najlepiej można wykorzystać w procesie zarządzania. Niestety, kryterium istotności rzadko pojawia się w klasycznym zestawie cech KPIs. W poszukiwaniu

1 W Polsce, Rosji i części krajów Europy Środkowo-Wschodniej thumaczy się je mylnie jako „kluczowe wskaźniki efektywności”. 
kryterium istotności dokonano przeglądu najczęstszych cech zidentyfikowanych na podstawie literatury.

Zdecydowanie najczęstszym zestawem cech prezentowanych w literaturze jest kryterium SMART. Zgodnie z nim kluczowe mierniki dokonań są:

- jasno określone (specific) - określenie miernika w jasny i zrozumiały sposób wymaga nazwania miernika, prezentacji sposobu obliczenia oraz zapewnienia właściwego odzwierciedlenia podejmowanych przez pracowników działań dla realizacji celów [Podgórski 2015]. Przekłada się to na fakt, że miernik powinien być zrozumiały dla tych, którzy będą się nim posługiwać [Podgórski 2015; Kjellen 2009; Rockwell 1959], lub innymi słowy musi być oczywiste to, co właściwie miernik przedstawia [Cardoso 2013];

- mierzalne (measurable) - oznacza techniczną możliwość przypisania KPIs określonej wartości. Wartość ta powinna być możliwa do identyfikacji i odczytu. Pomiar powinien zapewniać możliwie wysoką dokładność i powtarzalność (ten sam wynik na podstawie tych samych danych) [Podgórski 2015]. Dodatkowo ważnym aspektem mierzalności jest możliwość dokonywania porównań w czasie i przestrzeni pomiędzy różnymi jednostkami lub przedsiębiorstwami bez wysokich kosztów [Carlucci 2010];

- osiągalne (achievable) lub uchwytne (attainable) - osiągalność odnosi się do możliwości realizacji celów, których nie powinno być zbyt wiele [Deberdieva 2015]. Uchwytność - wskaźniki powinny być ,osiągalne” z wysiłkiem, ale realistyczne [Zhiqiang i in. 2011; Robinson $\mathrm{i}$ in. 2005];

- odniesione do kontekstu (relevant) - oznacza to, że miernik jest aktualny [Zhiqiang i in. 2011] oraz dostarcza informacji, które umożliwiają korektę podjętych działań w przyszłości [Carlucci 2010];

- określone w czasie (time-bound) - a więc z jednej strony dotyczące czasu, w którym dokonywany jest pomiar [Cardoso 2013], a z drugiej - zadań opisanych miernikiem, które należy wykonać w określonym czasie [Deberdieva 2015].

Istotność dla zarządzania nie jest, zgodnie z tym zestawieniem, cechą kluczowych mierników dokonań.

Badania, na które stosunkowo często powołują się także autorzy w literaturze, to badania warsztatowe D. Parmentera dla 3000 osób zarówno z sektora publicznego, jak i prywatnego, których owocem była identyfikacja siedmiu cech KPIs [Parmenter 2010, s. 6]:

- niefinansowe - opisane wielkościami niefinansowymi,

- na czas, a więc mierzone możliwie często,

- ukierunkowane na zarządzanie - na przykład stosowane przez decydentów,

- proste - każdy pracownik jest w stanie je wyliczyć i skorygować, jeżeli jest taka potrzeba,

- o znaczącym wpływie - miernik powinien odnosić się do kilku krytycznych czynników sukcesu, 
- o ograniczonej ciemnej stronie - mierniki powinny być trudne w manipulacji, promować właściwe zachowania.

Podobnie i w tym zestawieniu istotność miernika nie jest jednoznacznie określona, choć fakt, że KPI powinien być ukierunkowany na zarządzanie, może być pewnym tropem.

Zdaniem wielu naukowców samo określenie „kluczowy” stanowi o istotności tego miernika. Wówczas określenie ,kluczowy” można by traktować jako istotny dla zarządzania. Dla przykładu D. Parmenter doszukuje się kluczowości danego miernika $\mathrm{w}$ dostosowaniu do potrzeb informacyjnych podmiotu, a więc do jego cząstkowego lub syntetycznego charakteru [Parmenter 2010, s. 101]. W tym celu prezentuje model cebuli (rys. 1).

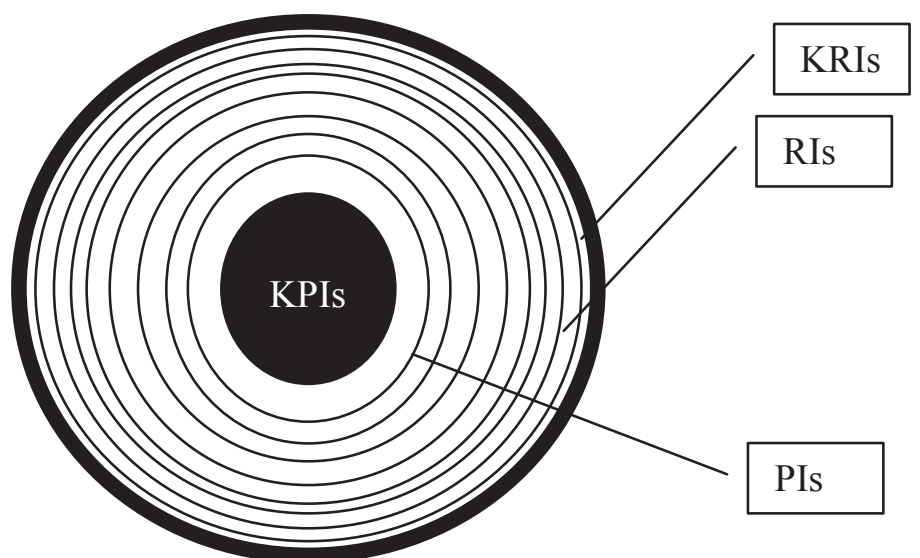

Rys. 1. Model cebuli prezentujący rodzaje mierników i problem „kluczowego” miernika Źródło: [Parmenter 2010].

Zgodnie z tym modelem mierniki KPIs można podzielić na [Parmenter 2010]:

1. Kluczowe mierniki dokonań wyprzedzające (KPIs) - są to mierniki cząstkowe, obrazujące kluczowy czynnik procesu lub modelu biznesu. Monitorowanie tego miernika umożliwia dokonywanie działań korygujących z wyprzedzeniem. Zgodnie z zasadą Pareto powinny one stanowić $80 \%$ mierników w systemie pomiaru dokonań [Parmenter 2007].

2. Kluczowe mierniki dokonań opóźnione (kluczowe mierniki wyniku, Key Results Indicators - KRIs) - są to mierniki syntetyczne opisujące często wynik danego zjawiska. Ich zadaniem jest monitorowanie realizacji celu/celów. Ponieważ są miernikami syntetycznymi, dlatego trudniej zidentyfikować przyczyny ich zmiany. Obrazują ogólny wynik podjętych działań. W tym rozumieniu są więc opóźnione w stosunku do KPIs wyprzedzających. Zgodnie z zasadą Pareto w systemie pomiaru dokonań powinno być ich 20\% [Parmenter 2007]. 
3. Mierniki dokonań wyprzedzające (Performance Indicators - PIs) - są to mierniki, które również mają charakter cząstkowy i są skoncentrowane na kluczowym czynniku procesu lub modelu biznesu, jednakże nie są kluczowe z punktu widzenia procesu zarządzania dokonaniami. Zazwyczaj są mierzone i mają charakter wspomagający. Mogą być też kluczowe dla innych (zwykle niższych) poziomów zarządzania dokonaniami.

4. Mierniki dokonań (wyniku) opóźnione (Results Indicators - RIs) - prezentujące również wyniki osiągnięte przez przedsiębiorstwo w danym obszarze, ale $\mathrm{w}$ sposób nie tak syntetyczny jak KRIs.

Sam koncept Pareto, przytoczony w powyższych rozważaniach, jest też rozumiany w szerszym kontekście. Zgodnie z tą zasadą $80 \%$ zjawisk wpływających pozytywnie na dokonania przedsiębiorstwa może być osiągnięty poprzez eliminację $20 \%$ przyczyn braku dokonań [Lam i in. 2007; Cooper, Schindler 2003]. Jest to więc zasada, która koncentruje uwagę raczej na istotnych kryteriach (miernikach) niż na tych mniej istotnych [Lam i in. 2007; Littlechild, Shutler 1991].

Podsumowując dotychczasowe rozważania - nie jest jasne, dlaczego kryterium istotności nie znajduje się w podstawowym zestawie cech kluczowych mierników dokonań, podczas gdy jest jednym z podstawowych kryteriów ich selekcji. Rozważania te będą kontynuowane w innych publikacjach autora.

\section{Metody selekcji kluczowych mierników dokonań bazujące na kryterium istotności}

Kryterium istotności wiąże się zazwyczaj z badaniami sondażowymi lub warsztatowymi. Badania te mogą przebiegać w odmienny sposób. Również forma identyfikacji istotności poszczególnych miar jest zależna od kontekstu badań. Zestawienie wybranych badań zaprezentowano w tabeli 1 .

Tabela 1. Metodologia selekcji wskaźników na podstawie kryterium istotności

\begin{tabular}{|c|c|c|c|}
\hline Autorzy & Metoda badania & $\begin{array}{c}\text { Forma identyfikacji } \\
\text { istotności }\end{array}$ & $\begin{array}{c}\text { Grupa } \\
\text { ankietowanych }\end{array}$ \\
\hline 1 & 2 & 3 & 4 \\
\hline $\begin{array}{l}\text { Bain i in. } 2002, \\
\text { Wallace i in. } 2000, \\
\text { Kinnie i in. } 2000, \\
\text { Robinson, Morley } \\
2006 \text {, Chakraborty, } \\
\text { Chuan } 2013\end{array}$ & Badania ankietowe & $\begin{array}{l}\text { Każdy miernik rangowany w } \\
\text { skali (np. 1-8) od nieistotne- } \\
\text { go do najbardziej istotnego }\end{array}$ & Pracownicy \\
\hline Bryde 2005 & Wywiad & $\begin{array}{l}\text { Jak stosowane mierniki są } \\
\text { wykorzystywane do zarzą- } \\
\text { dzania żelaznym trójkątem } \\
\text { kosztów, jakości i czasu }\end{array}$ & $\begin{array}{l}\text { Pracownicy przed- } \\
\text { siębiorstwa A i B, } \\
\text { marketing }\end{array}$ \\
\hline
\end{tabular}




\begin{tabular}{|c|c|c|c|}
\hline 1 & 2 & 3 & 4 \\
\hline Ham, Autekie 2005 & $\begin{array}{l}\text { Wywiad (e-mail, telefon, } \\
\text { kontakt osobisty), } \\
\text { ranking na podstawie } \\
\text { częstości wskazań }\end{array}$ & $\begin{array}{l}\text { Poproszenie o wybór najbar- } \\
\text { dziej istotnych miar }\end{array}$ & $\begin{array}{l}\text { Eksperci z firmy } \\
\text { i firm zewnętrznych }\end{array}$ \\
\hline $\begin{array}{l}\text { Dawood, Sikka } \\
2006\end{array}$ & $\begin{array}{l}\text { Technika deflicka oparta } \\
\text { na częściowo ustruktura- } \\
\text { lizowanym wywiadzie, } \\
\text { ranking zbudowany na } \\
\text { podstawie średniej }\end{array}$ & $\begin{array}{l}\text { Każdy miernik rangowany } \\
\text { w skali 1-4 od nieistotnego } \\
\text { do najbardziej istotnego }\end{array}$ & $\begin{array}{l}\text { Menedżerowie pro- } \\
\text { jektu i architekci }\end{array}$ \\
\hline Currie $i$ in. 2007 & $\begin{array}{l}\text { Wywiad strukturali- } \\
\text { zowany: ankietowani } \\
\text { najpierw wybierają kie- } \\
\text { runek pomiaru, później } \\
\text { rangują wybrany mier- } \\
\text { nik, ranking zbudowany } \\
\text { na podstawie średniej }\end{array}$ & $\begin{array}{l}\text { Każdy miernik rangowany } \\
\text { w skali 1-4 od nieistotnego } \\
\text { do najbardziej istotnego }\end{array}$ & Klienci \\
\hline $\begin{array}{l}\text { Stanley, Hensher } \\
2008\end{array}$ & Warsztaty & $\begin{array}{l}\text { Wybór istotnych mierników } \\
\text { do oceny efektywności } \\
\text { i skuteczności }\end{array}$ & Pracownicy \\
\hline Luu $\mathrm{i}$ in. 2008 & $\begin{array}{l}\text { Badanie ankietowe } \\
\text { + badanie zgodności } \\
\text { wewnętrznej }\end{array}$ & $\begin{array}{l}\text { Każdy miernik rangowany } \\
\text { w skali } 1-5 \text { od nieistotnego } \\
\text { do najbardziej istotnego, } \\
\text { drugie kryterium to odchyle- } \\
\text { nie standardowe }\end{array}$ & $\begin{array}{l}\text { Specjaliści } \\
\text { z 5-letnim stażem }\end{array}$ \\
\hline $\begin{array}{l}\text { Radujković } \mathrm{i} \text { in. } \\
2010 \text {; Eadie } \mathrm{i} \text { in. } \\
2013\end{array}$ & $\begin{array}{l}\text { Wywiad częściowo } \\
\text { ustrukturyzowany + } \\
\text { indeks relatywnej istot- } \\
\text { ności + testy statystycz- } \\
\text { ne (T-test, F-test) }\end{array}$ & $\begin{array}{l}\text { Każdy miernik rangowany } \\
\text { w skali np. 1-6 od nieistotne- } \\
\text { go do najbardziej istotnego + } \\
\text { indeks relatywnej istotności }\end{array}$ & $\begin{array}{l}\text { Inwestorzy, koope- } \\
\text { ranci, specjaliści }\end{array}$ \\
\hline Sawang 2011 & $\begin{array}{l}\text { Wywiad, test chi kwa- } \\
\text { drat istotności i faktu } \\
\text { stosowania + badanie } \\
\text { istotności }\end{array}$ & $\begin{array}{l}\text { Każdy miernik jest oceniany } \\
\text { pod kątem istotności (tak, } \\
\text { nie) i stosowania w praktyce } \\
\text { (tak, nie) }\end{array}$ & Przedsiębiorcy \\
\hline
\end{tabular}

Źródło: opracowanie własne.

Z zaprezentowanej metodologii wyjaśnienia wymaga indeks relatywnej istotności (RII) dla skali Likerta [Eadie i in. 2013; Chan, Kumaraswamy 1997]:

$$
\mathrm{RII}=\frac{\sum \text { waga miernika przyznana przez respondenta }}{\text { najwyższa } \text { wartóśc skali } \times \text { liczba respondentów }}
$$

lub dla skali 0-3:

$$
\mathrm{RII}=\frac{0 \times \text { liczba odp. } 0+33,3 \times \text { liczba odp. } 1+66,6 \times \text { liczba odp. } 2+100 \times \text { liczba odp. } 3}{\text { liczba respondentów }} .
$$

Prezentuje on wyniki w ujęciu procentowym, a nie przyjętej skali ocen. 
Poza przedstawioną metodologią istnieją także badania, w których kryterium istotności jest jednym z parametrów selekcji. Przykładem tego typu rozważań może być badanie Sawanga [2011].

\section{Badanie empiryczne}

W celu weryfikacji przytoczonej metodologii w 2014 roku przeprowadzono badanie ankietowe metodą CATI na próbie 300 przedsiębiorstw (100 firm z trzech klas wielkości - małych, średnich oraz dużych). Próba do badania została dobrana w sposób nieproporcjonalny z bazy REGON. Rozkład próby był następujący:

- $n=100$ przedsiębiorstw małych (zatrudnienie 10-49 osób),

- $n=100$ przedsiębiorstw średnich (zatrudnienie 50-249 osób),

- $n=100$ przedsiębiorstw dużych (zatrudnienie powyżej 250 osób),

W celu zapewnienia reprezentatywności przeprowadzonego badania opracowane zostały wagi analityczne, pozwalające odnieść wyniki badania na ogół polskich przedsiębiorstw. Dobrana próba była reprezentatywna ze względu na sekcję PKD oraz w obrębie każdej z klas wielkości firm. Wyniki badania zaprezentowano po uwzględnieniu wag wielkościowych [Niemiec (red.) 2016]. Dobór próby był dokonany w sposób analogiczny do badań m.in. Sawanga [2011].

Ankietowanych poproszono o odpowiedź na pytanie, czy stosują dany miernik na potrzeby zarządzania, a jeżeli tak, to jak oceniają istotność danego miernika w skali 1-5 (1 - nieistotny, a 5 bardzo istotny). Jeżeli miernik nie był stosowany na potrzeby zarządzania, przypisano 0 pkt. Jest to modyfikacja w stosunku do wcześniejszych badań zespołu (por. [Niemiec (red.) 2016]). W efekcie tego ostatniego zabiegu uzależniono wynik od częstości stosowania. Jest to zgodne z ideą podejścia m.in. Sawanga [2011], który bazuje na obu tych kryteriach przy selekcji KPIs. Wykazał on, że istnieje istotna statystycznie, znacząca zależność między istotnością danego miernika a faktem stosowania go w pomiarze dokonań. W obecnym badaniu zabieg ten uwidocznił skalę problemów związaną z samym kryterium istotności.

Na podstawie zebranych odpowiedzi zbadano ich wewnętrzną spójność za pomocą współczynnika alfa Cronbacha (tab. 2). Współczynnik ten informuje, do jakiego stopnia pewien zbiór zmiennych opisuje jeden ukryty w nim konstrukt.

Tabela 2. Metodologia selekcji wskaźników na podstawie kryterium istotności

\begin{tabular}{|c|c|c|}
\hline Współczynnik alfa Cronbacha & $\begin{array}{c}\text { Standaryzowany współczynnik } \\
\text { alfa Cronbacha }\end{array}$ & Liczba mierników \\
\hline 0,891 & 0,885 & 30 \\
\hline
\end{tabular}

Źródło: opracowanie własne. 
Alfa Cronbacha przyjmuje wartości od 0 do 1 . Im większa wartość, tym większa rzetelność skali. Przyjmuje się, że wartości powyżej 0,7 oznaczają prawidłową rzetelność skali. Tak jest w przeprowadzonym badaniu.

Ranking mierników został opracowany na podstawie średnich. W zestawieniu zaprezentowano także odchylenia standardowe.

Tabela 3. Ranking mierników KPIs

\begin{tabular}{|l|c|c|c|}
\hline \multicolumn{1}{|c|}{ Wyszczególnienie KPIs } & Średnia* & $\begin{array}{c}\text { Odchylenie } \\
\text { standardowe* }\end{array}$ & $\begin{array}{c}\text { Liczba } \\
\text { ankietowanych }\end{array}$ \\
\hline Zysk netto & 3,47 & 2,037 & 300 \\
\hline Przychody ze sprzedaży & 3,00 & 2,124 & 300 \\
\hline Rentowność & 2,66 & 2,224 & 300 \\
\hline Płynność finansowa & 2,24 & 2,246 & 300 \\
\hline Zadowolenie/satysfakcja klientów & 1,44 & 2,243 & 300 \\
\hline Pozyskanie nowych klientów & 1,32 & 2,028 & 300 \\
\hline Poziom zadłużenia i zdolności spłaty & 1,29 & 2,190 & 300 \\
\hline Lojalność klientów & 1,28 & 1,988 & 300 \\
\hline Kwalifikacje pracowników & 1,02 & 2,006 & 300 \\
\hline Wydajność pracy pracowników & 0,95 & 2,054 & 300 \\
\hline Koszt produktu, procesu & 0,85 & 2,014 & 300 \\
\hline Udział w rynku & 0,78 & 1,801 & 300 \\
\hline Wskaźniki podwyższania kwalifikacji & 0,77 & 1,883 & 300 \\
\hline Zadowolenie pracowników & 0,76 & 1,823 & 300 \\
\hline Wydajność maszyn i urządzeń & 0,67 & 1,817 & 300 \\
\hline Rentowność klientów & 0,66 & 1,696 & 300 \\
\hline Rotacja pracowników & 0,60 & 1,604 & 300 \\
\hline Reklamacje złożone, uznane & 0,58 & 1,794 & 300 \\
\hline Liczba nowych produktów & 0,56 & 1,468 & 300 \\
\hline Średnia płaca & 0,53 & 1,596 & 300 \\
\hline Czas wdrażania projektów & 0,52 & 1,586 & 300 \\
\hline EBIT, EBITDA & 0,49 & 1,874 & 300 \\
\hline Ekonomiczna wartość dodana eva & 0,43 & 1,557 & 300 \\
\hline Wskaźnik awaryjności maszyn i urządzeń & 0,42 & 1,628 & 300 \\
\hline Nakłady na badania i rozwój & 0,31 & 1,320 & 300 \\
\hline Inne mierniki finansowe & 0,27 & 0,938 & 300 \\
\hline Liczba zgłoszonych/wdrożonych wniosków patentowych & 0,13 & 0,891 & 300 \\
\hline Inne rodzaje mierników stosowane do oceny procesów & 0,07 & 0,715 & 300 \\
\hline Inne rodzaje mierników & 0,01 & 0,326 & 300 \\
\hline Inne odnoszące się do klienta specyficzne dla państwa & & & 300 \\
\hline przedsiębiorstwa & 0,00 & 0,289 & \\
\hline & & & \\
\hline
\end{tabular}

* Ważone wagami analitycznymi.

Źródło: opracowanie własne. 
Wyniki przeprowadzonego badania ujawniają słabości kryterium istotności jako głównego kryterium selekcji mierników KPIs. Pierwszym i podstawowym elementem jest fakt, że jedynie 3 pierwsze mierniki posiadają istotność większą od odchylenia standardowego. Oznacza to, że w opiniach respondentów panuje pozorna zgodność, że są to mierniki najbardziej istotne z punktu widzenia zarządzania. Są to mierniki opisujące zysk netto, przychody ze sprzedaży oraz rentowność. Wszystkie te miary są miernikami finansowymi. Ich zakres jest syntetyczny, a z racji tego są miernikami opóźnionymi. Dodatkowo zasada Pareto nie jest spełniona.

\section{Dyskusja}

Wyniki analizy w tym przypadku dają więcej pytań niż odpowiedzi. Pierwsze pytanie, jakie należałoby zadać, to: dlaczego miary finansowe są na szczycie rankingu? Odpowiedź wydaje się stosunkowo prosta. Nadal pomiar osiągnięć jest prowadzony głównie na poziomie płaszczyzny finansowej. Zgodnie z badaniami B. Marra $87 \%$ respondentów mierzy dokonania w tym właśnie obszarze na potrzeby zarządzania dokonaniami. Dużo mniej, bo $75 \%$, mierzy dokonania w ramach procesów wewnętrznych działalności operacyjnej, $69 \%$ w obszarze klienta i $68 \%$ aspekty dotyczące pracowników. Wyraźnie widać, że ranking istotności jest wysoce wrażliwy na postrzeganie istotności samych procesów w przedsiębiorstwie [Marr 2012]. Potwierdzają to także badania, które prowadzili A. Chakraborty i T.K. Chuan.

Drugą wadą jest fakt, że w opinii respondentów wyższy priory tet posiadają wyniki niż działania. Można to także zauważyć w badaniach, które prowadzili np. A. Chakraborty i T.K. Chuan. Inni autorzy, jak W.L. Currie i inni, N. Dawood, S. Sikka, J.C. van Ham i P. Autekie, ograniczyli badane mierniki do mierników procesu. Skutkiem tego jest brak zachowania zasady Pareto przy selekcji mierników. Wybrane mierniki mają natomiast charakter syntetyczny, opóźniony. Jest to spowodowane po części zerową oceną w przypadku braku stosowania wybranego miernika, a po części ze względu na dobór próby badawczej. W badaniu ankietowani byli właściciele, menedżerowie i specjaliści. Stąd może wynikać większa koncentracja na wynikach, a mniejsza na działaniach.

Trzecią wadą jest wysoka zmienność odpowiedzi. Jest ona efektem wprowadzenia zerowej oceny w przypadku braku stosowania wybranego miernika, ale także jest spowodowana doborem próby badawczej. W badaniu ankietowane były wspomniane osoby z przedsiębiorstw różnej wielkości. Wyniki są reprezentatywne ze względu na wielkość przedsiębiorstwa w gospodarce polskiej. Ze względu na strukturę gospodarki polskiej dominują opinie o istotności mierników reprezentowane przez decydentów w przedsiębiorstwach małych i średnich. To może być także przyczyną dużej zmienności odpowiedzi. 


\section{Zakończenie}

Czy zatem kryterium istotności powinno mieć rację bytu w selekcji kluczowych mierników dokonań? Odpowiedź na to pytanie zależy w dużej mierze od przyjętej metodologii i zakresu prowadzenia badań.

Na podstawie powyższych wniosków należy zaznaczyć, że kryterium istotności może być ważne w identyfikacji kluczowych mierników dokonań opóźnionych spośród większego zbioru opóźnionych mierników dokonań (ewentualnie kluczowych mierników dokonań wyprzedzających spośród zbioru wyprzedzających mierników). Unika się wówczas promocji mierników syntetycznych, wynikowych.

Drugim elementem jest właściwe sformułowanie pytania badawczego. Postrzegana istotność na potrzeby zarządzania może również promować wielkości syntetyczne, wynikowe. Pytanie o istotność KPIs do zarządzania żelaznym trójkątem kosztów, jakości i czasu może okazać się lepszym wyborem, ponieważ odnosi się bardziej do idei dokonań.

Trzecim elementem jest wybór respondentów. Wydaje się bardziej zasadne, aby respondentami byli pracownicy przedsiębiorstwa, a w tym specjaliści i osoby technicznie związane z mierzonym procesem. Będą to bowiem potencjalni użytkownicy powstającego systemu. Włączenie osób z zewnątrz może skutkować brakiem spójności w odpowiedziach i w efekcie dużą ich zmiennością. Dzięki właściwemu doborowi ankietowanych można też wpływać na wyniki postrzegania istotności.

Odpowiadając więc na pytanie, czy kryterium istotności powinno mieć rację bytu w selekcji kluczowych mierników dokonań, można powiedzieć, że tak. Jednakże ze względu na swój charakter powinna być metodą uzupełniającą proces selekcji mierników KPIs, a nie wiodącą.

\section{Literatura}

Bain P., Watson A., Mulvey G., Taylor P., Gall G., 2002, Taylorism, targets and the pursuit of quantity and quality by call centre management, New Technology, Work and Employment, vol. 17, no. 3, s. $170-185$.

Bryde D.J., 2005, Methods for managing different perspectives of project success, British Journal of Management, no. 16, vol. 2, s. 119-131.

Cardoso E.C.S., 2013, Challenges in performance analysis in enterprise architectures, Proceedings IEEE International Enterprise Distributed Object Computing Workshop, EDOC, s. 327-336.

Carlucci D., 2010, Evaluating and selecting key performance indicators: an ANP based model, Meas. Bus. Excellence, vol. 14(2), s. 66-76.

Chakraborty A., Chuan T.K., 2013, An empirical analysis on six sigma implementation in service organisations, International Journal of Lean Six Sigma, no. 4, vol. 2, s. 141-170

Chan D., Kumaraswamy D., 1997, A comparative study of causes of time overruns in Hong Kong construction projects, International Journal of Project Management, vol. 15, no. 1, s. 55-63. 
Cokins G., 2009, Performance Management. Integrating Strategy Execution, Methodologies, Risk, and Analytics, John Wiley \& Sons Inc., Hoboken.

Companies Act, 2006, London.

Cooper D.R., Schindler P.S., 2003, Business Research Methods, McGraw-Hill, Irwin.

Currie W.L., Joyce P., Winch G., 2007, Evaluating application service provisioning using system dynamics methodology, British Journal of Management, no. 18, vol. 2, s. 172-191.

Dawood N., Sikka S., 2006, The value of visual 4D planning in the UK construction industry, Lecture Notes in Computer Science (including subseries Lecture Notes in Artificial Intelligence and Lecture Notes in Bioinformatics), no. 4200 LNAI, s. 127-135.

Deberdieva E.M., 2015, Key performance indicators as an instrument of achieving strategic indicators of oil and gas producers, Mediterranean Journal of Social Sciences, no. 6, vol. 3, S3, s. 19-30.

Eadie R., Millar P., Toner L., 2013, Public private partnerships, reevaluating value for money, International Journal of Procurement Management, no. 6, vol. 2, s. 152-169.

Ham J.C. van, Autekie P., 2005, Container terminals in the Mediterranean region, WIT Transactions on the Built Environment, no. 79, s. 449-458.

Kinnie N., Hutchison S., Purcell J., 2000, 'Fun and surveillance': the paradox of high commitment management in call centres, The International Journal of Human Resource Management, vol. 11, no. 6, s. 967-985.

Kjellen U., 2009, The safety measurement problem revisited, Safety Science, vol. 7 (4), s. 486-489.

Lam E.W.M., Chan A.P.C., Chan D.W.M., 2007, Benchmarking the performance of design build projects Development of project success index, Benchmarking: An International Journal, vol. 14 iss 5, s. 624-638.

Lebas M.J., 1995, Performance measurement and performance management, International Journal Production Economics, vol. 41, s. 23-35.

Littlechild S., Shutler M., 1991, Operations Research in Management, Prentice-Hall, Englewood Cliffs.

Luu V.T., Kim S.-Y., Huynh T.-A., 2008, Improving project management performance of large contractors using benchmarking approach, International Journal of Project Management, no. 26, vol. 7, s. $758-769$.

Marr B., 2012, 20 Years of Measuring and Managing Business Performance. From KPI and Dashboards to Performance Analytics and Big Data, Advanced Performance Institute, Milton Keynes.

Niemiec A. (red.), 2016, System pomiaru dokonań w przedsiębiorstwach, CeDeWu, Warszawa.

Parmenter D., 2007, Pareto's 80/20 Rule for Corporate Accountants, John Wiley \& Sons Inc., Hoboken.

Parmenter D., 2010, Key Performance Indicators Developing, Implementing, and Using Winning KPIs, John Wiley \& Sons Inc., Hoboken.

Paulen B., Finken J., 2009, Pro SQL Server 2008 Analytics. Delivering Sales and Marketing Dashboards, Springer-Verlag, New York.

Podgórski D., 2015, Measuring operational performance of OSH management system - A demonstration of AHP-based selection of leading key performance indicators, Safety Science, no. 73, s. 146-166.

Radujković M., Vukomanović M., Burcar Dunović I., 2010, Application of Key Performance Indicators in South-Eastern European construction, Journal of Civil Engineering and Management, no. 16 , vol. 4 , s. 521-530.

Robinson G., Morley C., 2006, Call centre management: Responsibilities and performance, International Journal of Service Industry Management, no. 17, vol. 3, s. 284-300.

Robinson H.S., Anumba C.J., Carillo P.M., Al-Ghassani A.M., 2005, Business performance measurement practices in construction engineering organisations, Measuring Business Excellence, no. 9, vol. 1, s. 13-22.

Rockwell T.H., 1959, Safety performance measurement, Journal of Industrial Engineering, vol. 10, s. 12-16. 
Sawang S., 2011, Key performance indicators for innovation implementation: Perception vs. actual usage, Asia Pacific Management Review, no. 16, vol. 1, s. 23-29.

Stanley J., Hensher D.A., 2008, Delivering trusting partnerships for route bus services: A Melbourne case study, Transportation Research Part A: Policy and Practice, no. 42, vol. 10, s. 1295-1301.

Wallace C.M., Eagleson G., Waldersee R., 2000, The sacrificial HR strategy in call centers, International Journal of Service Industry Management, vol. 11, no. 2, s. 174-184.

Zhiqiang J., Xilan F., Xianzhang F., Jinfa S., 2011, A study of the demonstration on KPI performance examination for aviation SP enterprise of XAC, Communications in Computer and Information Science, no. 233 CCIS, vol. PART 3, s. 453-464. 